\title{
A review of the powderpost beetle genera Xylothrips Lesne, 1901 and Calophagus Lesne, 1902 (Coleoptera: Bostrichidae: Bostrichinae: Xyloperthini)
}

\author{
Lan-Yu LIU \\ Department of Science Communication, National Pingtung University, No.1, \\ Linsen Rd, Pingtung City, Pingtung County 90049, Taiwan. \\ Email: liulysky@gmail.com \\ urn:1sid:zoobank.org:author:2A7CCDB9-5AA5-4C96-821F-64867C4E29C0
}

\begin{abstract}
This paper reviews the genera Xylothrips Lesne, 1901 and Calophagus Lesne, 1902, and their species, and proposes that Calophagus should be reinstated as a full genus from a subgenus of Xylothrips (contra Borowski \& Węgrzynowicz 2019). The genera and their included species are diagnosed and redescribed, and a summary of information on the distribution and biology of all species is provided. The importance of characters of the antennal club and pronotum in separating the two genera is stressed. A key to the two genera and the two species of Xylothrips is provided.
\end{abstract}

Keywords. Review, Xylothrips, Calophagus, reinstatement.

Liu L.-Y. 2021. A review of the powderpost beetle genera Xylothrips Lesne, 1901 and Calophagus Lesne, 1902 (Coleoptera: Bostrichidae: Bostrichinae: Xyloperthini). European Journal of Taxonomy 746: 130-147.

https://doi.org/10.5852/ejt.2021.746.1325

\section{Introduction}

The tribe Xyloperthini Lesne, 1921 is the most species-rich in Bostrichidae Latreille, 1802, and currently includes 33 genera (Borowski \& Węgrzynowicz 2007, 2019; Park et al. 2015; Liu et al. 2016; Liu \& Beaver 2017). The tribe has a world-wide distribution, but the individual genera are mostly confined to a single zoogeographical region or subregion (Borowski \& Węgrzynowicz 2007).

The genus Xylothrips Lesne (1901) was erected for three species of Apate, one, A. flavipes Illiger, 1801, from Madagascar and Indo-Malaysia, the second, A. religiosus Boisduval, 1835, from the archipelagos of the Pacific Ocean, and the third, A. geoffroyi Montrouzier, 1861, from Art Island to the northwest of the main island of New Caledonia. One year later, Lesne (1902) erected Calophagus for his new species, Calophagus pekinensis, from northern China.

Lesne did not assign a type species for Xylothrips when he erected the new genus. Chûjō (1937) designated Apate flavipes Illiger, 1801 as the type species. Even though Lesne (1901) listed Xylothrips (?) Geoffroyi [sic!], he did not include the species in his key to the species of Xylothrips, although he later included it in his world catalogue of Bostrichidae (Lesne 1938a). Borowski \& 
Węgrzynowicz (2019) synonymised Xylothrips geoffroyi with Xylothrips religiosus (Boisduval, 1835), suggesting that Montrouzier (1861) had confused the sexes of the same species as two species. Reichardt (1966) added one new species to this genus, Xylothrips cathaicus, based on 5 female individuals from Hebei (Hopeh) and Henan (Honan), as the only species of the genus known from China.

Lesne (1902) mentioned that the genus Calophagus greatly resembled the palaeotropical Xylothrips, although the only known species, Calophagus pekinensis, occurs in northern China (Beijing). Lesne gave "the absence of the lateral ridge of the prothorax" and "the ornamentation of the segments of the antennal club" as the essential characters distinguishing Calophagus from Xylothrips. When Reichardt (1966) described X. cathaicus, he mentioned that the prothoracic lateral ridges are only vaguely indicated, but did not mention the ornamentation of the segments of the antennal club at all. Park et al. (2015) synonymised Calophagus pekinensis with Xylothrips cathaicus as Xylothrips pekinensis without examining the type material (Dr Park, pers. comm.). Borowski \& Węgrzynowicz (2019) agreed with Park et al., and downgraded Calophagus to a subgenus of Xylothrips. The present paper studies the essential characters of the two genera, then reinstates Calophagus as a valid genus, rather than a subgenus of Xylothrips, and includes X. cathaicus as a synonym of Calophagus pekinensis. A key is provided to distinguish the species of Xylothrips and Calophagus.

\section{Material and methods}

In the course of this study, the author has examined all available types, other specimens of Xylothrips and Calophagus in numerous European museums and certain private collections, and the online database of insect types of the Museum of Comparative Zoology, Harvard University.

The following abbreviations are used for museums and private collections:

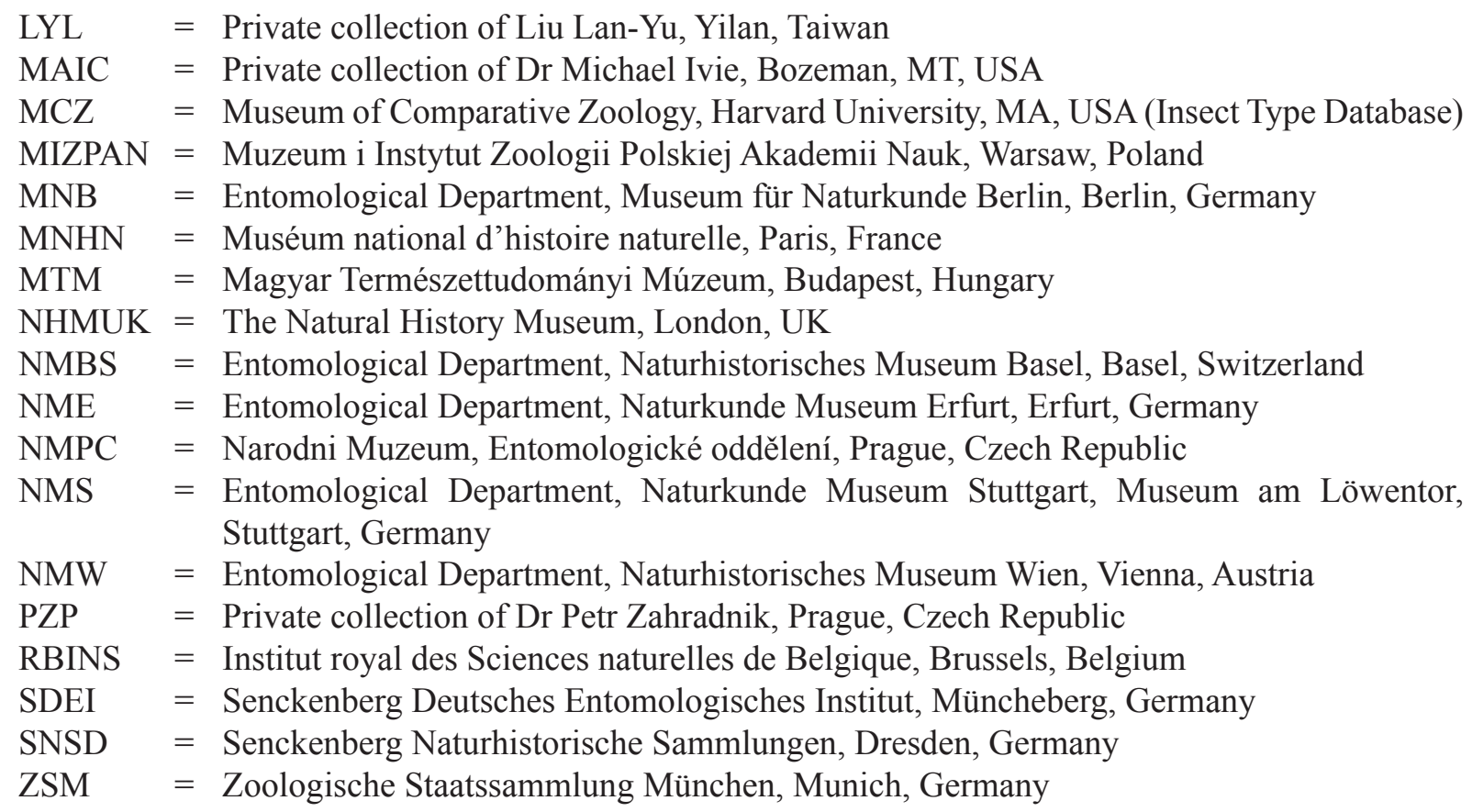

Photographs were taken with a Panasonic Lumix GX8 digital camera, combined using the program CombineZP, and optimized with Adobe Photoshop CS2.

The descriptions of the species are mainly based on Lesne (1901, 1902), with additional characters obtained by the examination of specimens from the museums and collections listed above. 


\title{
Results
}

Taxonomy

\author{
Class Insecta Linnaeus, 1758 \\ Order Coleoptera Linnaeus 1758 \\ Superfamily Bostrichoidea Latreille, 1802 \\ Family Bostrichidae Latreille, 1802 \\ Subfamily Bostrichinae Latreille, 1802 \\ Tribe Xyloperthini Lesne, 1921
}

Genus Xylothrips Lesne, 1901

Figs $1 \mathrm{C}-\mathrm{F}, 2-3$

Xylothrips Lesne, 1901: 620 (type species: Apate flavipes Illiger, 1801: 171 by subsequent designation in Chûjō 1937: 58).

\section{Diagnosis}

As a member of Xyloperthini, the genus is characterised by the lamelliform intercoxal process of the first abdominal ventrite, the mandibles crossed at the tips and the well-developed to elongated antennal club (Lesne 1921; Fisher 1950; Liu \& Schönitzer 2011). The genus is distinguished from all other genera of Xyloperthini by the following combination of characters: antenna with ten antennomeres, the funicle with five, and club with three antennomeres, the funicle as long as the first club segment with a rim of long, erect hairs around each segment, antennal club matt without clear sensory impressions or stiff hairs, with a series of erect hairs on the inner side and one long erect hair on the anterolateral angle of each club segment (Fig. 1C, E); long and distinct lateral ridge-like carinae on pronotum (Fig. 1D, F), which form the acute posterolateral angles of the pronotum; elytral suture slightly raised behind the summit of declivity, but not swollen at all (Figs 2D, 3B); both sexes with pleural pieces at sides of last ventrite (Fig. 2E). The species are 5.5-8.5 mm long.

Compared with Xylothrips, the other four genera of Xyloperthini with ten antennomeres which occur in the same geographical area, i.e., Calonistes Lesne, 1936, Xylocis Lesne, 1901, Xylophorus Lesne, 1906 and Paraxylion Lesne, 1941, can be distinguished by the lack of lateral carinae on the pronotum and being less than $5.5 \mathrm{~mm}$ in length. Paraxylion can also be distinguished by the two circular sensory areas close to the anterior margin on the first and second club antennomeres. In the tribe Xyloperthini, only Amintinus Anonymous, 1939 (Ivie 2010), Xylopsocus Lesne, 1901 and Xylothrips possess the ridgelike 'true' lateral carina of the pronotum (Lesne 1932, 1938b). Amintinus is an African genus with species about 3.0-3.5 mm in length without marginal tubercles on the elytral declivity, the lateral margin prominent and the lower apical margin thickened, emarginated. Xylopsocus can be distinguished by the lack of pleural pieces at the sides of the last ventrite of the male, smaller size (about 3.5-4.5 mm in length) and the presence of only 9 antennomeres in a few species (X. capucinus (Fabricius, 1781), X. intermedius Damoiseau in Damoiseau \& Coulon, 1993 and X. radula Lesne, 1901).

\section{Description}

Body. Elongate, cylindrical, 5.5-8.5 mm long.

HEAD. Deeply inserted in prothorax, not visible from above. Frons simple, finely punctured, with upwardly directed hairs, denser and much longer in female, fronto-clypeal suture distinct, strongly impressed in middle; clypeus transverse, anterior margin forms an arc in the middle, finely and densely punctured; 

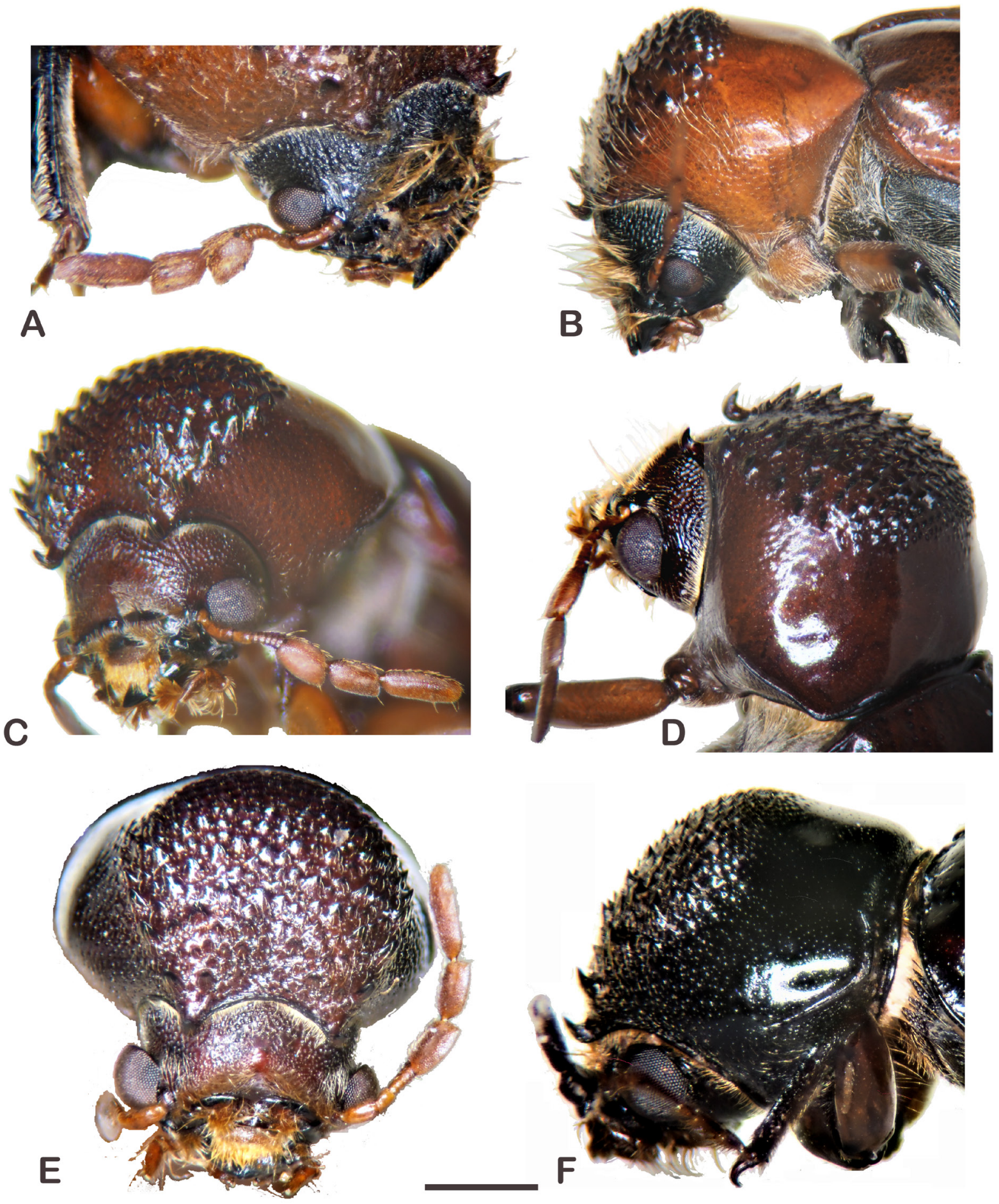

Fig. 1. A-B. Calophagus pekinensis Lesne, 1902, o (SNSD). A. Anterolateral view showing the antennae, with two strips of golden hairs on sides. B. Lateral view of head and pronotum showing absence of lateral carina on pronotum. C-D. Xylothrips flavipes (Illiger, 1801), ठิ (LYL). C. Frontal view showing the antennae, matt without sensory areas. D. Lateral view of head and pronotum showing clear lateral carina on pronotum. E-F. Xylothrips religiosus (Boisduval, 1835), ठิ (LYL). E. Frontal view showing the antennae, matt without sensory areas. F. Lateral view of head and pronotum showing clear lateral carina on pronotum. Scale bar $=1 \mathrm{~mm}$. 
labrum transverse with a fringe of long hairs along anterior margin. Mandibles subequal, sharply pointed. Eyes rather large, oval, detached from temples posteriorly. Antenna with 10 antennomeres, first two elongate, antennomeres 3-7 forming a funicle, each antennomere transverse, the fifth widest, together about as long as first antennomere of club, antennomeres 8-10 forming elongate club, about twice as long as rest of antenna; lacking distinct, clearly defined sensory impressions or stiff hair area on all antennomeres; first two antennomeres of antennal club about 1.2-1.5 times as long as wide and last antennomere slender, about $2-3$ times as long as wide, elongate oval.

Pronotum. Slightly wider than long, anterior angles with a rather long, upcurved uncinate tooth; sides moderately to broadly rounded, attenuated anteriorly, widest close to posterior margin of pronotum; anterior margin between unci concave, rugose; area above anterior margin flat or weakly impressed, and strongly, densely punctured; with a series of upwardly-directed teeth laterally, gradually reduced in size from anterior to posterior, mixed with small teeth and tubercles to summit of pronotum, with fine, shallow, well-separated punctures; sides with distinct ridge-like lateral carinae which extend along posterior margin and form sharply tipped posterolateral angles; ventro-lateral punctures with sparse, long, white pubescence.

ScutelLum. Small, tongue-shaped, finely punctured or glabrous, shining.

ElytRA. Subequal to pronotum in width, strongly convex, shining, and strongly, evenly punctured, almost glabrous on disc and declivity, only sparse and very tiny pubescence on apical part of declivity, sutural margin slightly raised from summit to near apex of declivity and rather strongly raised at apex of declivity. Upper margin of declivity with three pairs of tubercles and one pair of elongate calluses at side.

ABDomen. Ventral side covered by short, white pubescence, last ventrite with narrow pleural pieces along margin and a tuft of long hairs in middle in both sexes.

Legs. Subequal in length, procoxae contiguous, mesocoxae narrowly separated, pro- and mesotibiae grooved on external face, widened to apex. Posterior tibiae with a few long bristles on outer side, very dense, short, golden hairs rimming ventroposterior margins of posterior femora. Second and third segments of tarsi usually distinctly wider than following segments.

\section{Sexual dimorphism}

The genus shows clear sexual dimorphism in the vestiture of the frons. In the female, the frons is more densely and finely punctured, and the upwardly directed hairs are much longer and denser than in the male. The frontal hairs are yellowish, forming a crown with rather short, erect hairs inside. In the male, the frontal hairs are short with only a small tuft of very long hairs next to the eyes.

\section{Biology}

As a member of the dry wood borer family Bostrichidae, Xylothrips usually occurs in forest habitats (pers. obs.). From the records of host plants, the genus, like almost all other bostrichids, is certainly polyphagous and attacks orchard trees as well as forest trees (Lesne 1901, 1932; Stebbing 1914; Beeson \& Bhatia 1937). In tropical areas, there is more than one generation per year (Beeson \& Bhatia 1937), and high populations can cause economic problems in orchards and other forest plantations.

\section{Distribution}

India, Nepal, Southeast Asia, Australia, the archipelagos of the Indian Ocean and Pacific Ocean, Madagascar. 
Xylothrips flavipes (Illiger,1801)

Figs $1 \mathrm{C}-\mathrm{D}, 2$

Apate flavipes Illiger, 1801:171 (male).

Apate dominicanus Fabricius, 1801: 380 (female). Synonymy in Lesne 1901: 621.

Bostrichus mutilatus Walker, 1858: 286. Synonymy in Lesne 1901: 622.

Bostrichus iracundus Snellen van Vollenhoven, 1869: 10. Synonymy in Lesne 1901: 622.

Apate sinuatus (non Fabricius, 1792) - Stephens 1830: 351. Synonymy in Lesne 1901: 622.

Apate religiosae - Fairmaire 1850: 50 (in part). Synonymy in Lesne 1901: 622.

\section{Diagnosis}

This species is easily separable from $X$. religiosus by the reddish brown body, the shallower frontoclypeal suture, the absence of punctures on the lateral part of the pronotum, the extension of the inferolateral callus, which converges into the lower lateral margin of the elytra (Fig. 2B), and the apical sutural angles raised with tubercles beneath the margin.

\section{Material examined}

The author has examined the type of Apate flavipes from 'Afrika' in MNB, and the type of Bostrichus mutilatus from Sri Lanka (Ceylon) in NHMUK. The author has also examined more than 1000 specimens identified by Lesne, Vrydagh and others in 13 museums (RBINS, MIZPN, MNB, MTM, NHMUK, NMBS, NME, NMPC, NMS, NMW, SDEI, SNSD and ZSM) as well as in private collections (LYL, MAIC and PZP), mainly from Southeast Asia and the archipelagos of the Indian Ocean and Madagascar, but detailed locality data were not recorded.

\section{New records}

The author received 10 specimens collected from Xishuangbanna, Yunnan, China. This is the first record of the species from China. The data for the specimens are as follows:

CHINA -1 đ̃; S Yunnan, Xishuang-banna, S Yunnan, $20 \mathrm{~km}$ NW of Jinghong Man Dain (Nabanhe National Nature Reserve); $22^{\circ} 07^{\prime} 80^{\prime \prime}$ N, 100 $40^{\prime} 05^{\prime \prime}$ E; alt. 730 m; 18 Jul. 2008; A. Weigel leg.; forest;

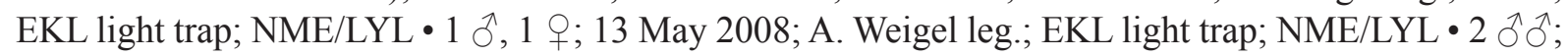
6 Apr. 2009; L. Meng leg.; EKL light trap; NME/LYL • 1 đ̂ं; 26 km NW of Jinghong, near An Man Xin Zhai; $22^{\circ} 11^{\prime} 45^{\prime \prime} \mathrm{N}, 100^{\circ} 38^{\prime} 44^{\prime \prime} \mathrm{E}$; alt. 760 m; 10 Oct. 2008; L. Meng leg.; forest; EKL light trap; NME/

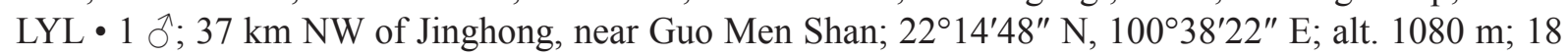
Jul. 2008; A. Weigel leg.; UWP MF Malaise trap; NME/LYL・1 ð̊; 27 Apr. 2009; light; NME/LYL.

In addition, two more specimens were collected from the branches of a rubber tree (Hevea brasiliensis Müll.Arg.) in Jinghong, Xishuangbanna during Jan. 2018 (S.C. Lai, pers. comm.).

\section{Description}

Body. 6-8.5 mm long, about 2-2.3 times as long as wide, elongate. Head, pronotum, abdomen and disc of elytra testaceous, posterior of elytra and declivity dark brown, antennae reddish, club often brown; femora testaceous, tibiae and tarsi brownish.

HEAD. Clypeus finely and densely punctured, concave in an arc in front. Fronto-clypeal suture distinguished by different colour between frons and clypeus or shallow suture with vertical longitudinal furrow in middle ending on anterior margin of clypeus. Frons with punctures less fine and less dense than on clypeus, slightly rough, covered by fairly long, fine pubescence directed upwards. First antennomere elongated, second antennomere sub-rectangular, each funicle segment with a rim of long hairs in middle, 
total length of funicle as long as or shorter than first antennomere of antennal club, first and second antennomeres of antennal club 1.3-1.5 times as long as wide, last antennomere rather elongated, about 2.5-3 times as long as wide. Club matt, without clear sensory impressions or an area with stiff hairs (Fig. 1C).

Pronotum. About 1.2-1.3 times as wide as long, fairly strongly narrowed in anterior third, widest in basal part; a distinct upwardly-directed uncinate tooth on anterolateral angle and a series of upwardlydirected teeth behind form lateral border of rasp on anterior half of pronotum, teeth gradually smaller and less erect towards summit of pronotum and posterior border of rasp formed by small tubercles or granules, bearing yellowish-red, short, recumbent pubescence between teeth (Fig. 2A, D); area above anterior margin between uncinate teeth finely and more or less roughly punctured; median and posterior areas shiny with fine, sparse punctures; sides evenly rounded behind rasp; distinct, ridge-like lateral carinae extended to basal margin of pronotum to form pointed posterolateral angles (Fig. 1D). Basal half of pronotum with minute, moderately dense punctures in middle only; laterally shining, glabrous, tiny white hairs present close to infero-lateral margin (Fig. 1C).

ELYTRA. 1.7-1.85 times as long as pronotum, 1.45-1.65 times as long as wide, disc parallel-sided, widest at middle of declivity. Elytra shining, with sparse, moderately fine and shallow punctures on disc, becoming deeper and larger on posterior part of disc and declivity, upper half of declivity with strongest punctures. Upper margin of elytral declivity with three pairs of tubercles, middle one largest, with pointed tip and projecting furthest, other two forming short ridges with rounded tips, infero-lateral callus extended and joining directly to infero-lateral margin of elytra (Fig. 2B-C). Elytral suture raised from upper margin of declivity and gradually swollen and thickest at apex, where it forms rounded thickened angles, margin of elytra with one or several tubercles on ventral side near sutural angle, which projects slightly.
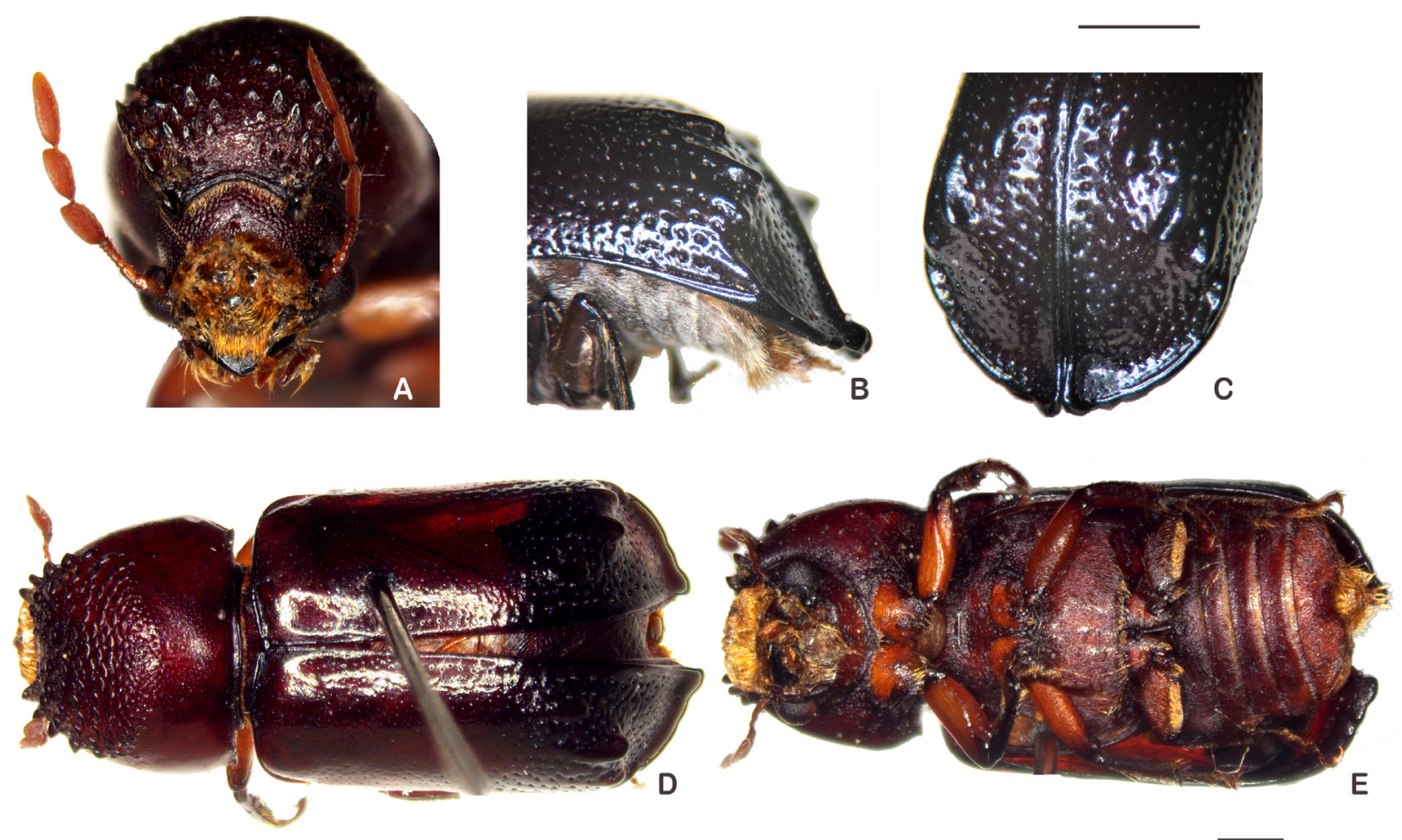

Fig. 2. Xylothrips flavipes (Illiger, 1801), $q$ (LYL). A. Frontal view. B. Lateral view of declivity. C. Declivity. D. Dorsal view. E. Ventral view. Scale bars $=1 \mathrm{~mm}$ (upper scale for A-C; lower scale for D-E). 
ABDomen. Ventral side vestiture with dense, white or reddish yellow pubescence, last ventrite with narrow pleural pieces along margin to apical curved area, with a long tuft of hairs in middle.

LEGs. Dense, short golden hairs on ventroposterior margins of posterior femora (Fig. 2E). External face of pro- and mesotibiae broadly grooved, not narrowed towards apex. Segments 2 and 3 of anterior tarsi distinctly wider than others.

\section{Male}

HEAD. Frons transversely convex, densely and very finely punctured, very finely pubescent, with a few erect hairs next to inner margin of eyes. Clypeus with a transverse band of upwardly directed hairs towards base with a narrow median line (Fig. 1C).

\section{Female}

HEAD. Frontal crown of hairs very thick, forming arc of a circle or a very wide V, fairly distant laterally from eyes. Clypeal tufts of hairs as long as those on frons (Fig. 2A, D-E).

\section{Remarks}

Waterhouse (1888) transferred Bostrichus mutilatus Walker, 1858 to Xylopertha, noting that material he examined bore the name "religiosa Dej.", and that it was very similar to material deposited in NHMUK as Apate lifuana Montrouzier, 1861. Lesne (1901) later synonymised Xylopertha mutilatus with Xylothrips flavipes.

\section{Biology}

Stebbing (1914) recorded X. flavipes attacking cocoa trees (Malvaceae: Theobroma cacao L.), in Mauritius, and researchers have observed this species in the wood of banyan (Moraceae: Ficus religiosa L.) and badanier (Combretaceae: Terminalia catappa L.), the latter a species native to India. In India, X. flavipes has been recorded living in the wood of the mango tree (Anacardiaceae: Mangifera indica L.), sal (Dipterocarpaceae: Shorea robusta Roth), cocoa, rubber (Euphorbiaceae: Hevea brasiliensis), etc. (Lesne 1932). Beeson \& Bhatia (1937) listed host plants belonging to 13 families in India:Anacardiaceae (Anacardium, Lannea), Burseraceae (Canarium), Dipterocarpaceae (Dipterocarpus, Hopea, Vateria and Vatica), Fagaceae (Quercus), Euphorbiaceae (Mallotus), Lauraceae (Persea), Leguminosae (Albizia, Butea, Caesalpinia), Malvaceae (Bombax), Moraceae (Ficus), Myristicaceae (Knema), Myrtaceae (Syzygium), Phyllanthaceae (Phyllanthus), Vitaceae (Vitis) and several unidentified woods. It is apparent that $X$. flavipes is a polyphagous species. It has usually been collected from forests or orchards, not lumber yards, timber processing premises or wooden items.

Beeson \& Bhatia (1937) found that X. flavipes has two generations a year in North India and recorded the first generation emerging from the end of March to the end of May, with maximum abundance in the third week of April, a second generation from the first week of July to the third week of October. From logs of Mangifera indica (Anacardiaceae) felled in August, X. flavipes was found to have a minimum life-cycle of three months (Beeson \& Bhatia 1937). Sittichaya et al. (2013) surveyed the durian-based orchards in Southern Thailand and found $X$. flavipes was the dominant species in the durian growing areas.

\section{Distribution}

The distribution includes: Madagascar, Indian Ocean islands, Sri Lanka, India, Nepal, China (Yunnan), Southeast Asia, Philippines, Indonesia. It has probably been introduced through human agency into the Mariana Is., Palau and the Federated States of Micronesia in the Western Pacific. It has also been introduced into the Arabian Peninsula, Socotra Island (Yemen), South Africa (Natal), Israel, Europe and USA (Borowski \& Węgrzynowicz 2007, 2019). Roberts (1968) recorded the species in Sapele, 
Nigeria at light. There are more than 10 specimens deposited in MNB and 7 specimens in SDEI from Ethiopia. This suggests that the species is established in that country. In the RBINS collection, there is one specimen (Vrydagh ident.) collected from NSW, Australia in 1914 from imported wood from India, and one specimen from Melbourne, Australia in SDEI. These appear to be accidental introductions.

Xylothrips religiosus (Boisduval, 1835)

Figs 1E-F, 3

Apate religiosa Boisduval, 1835: 460.

Apate destructor Montrouzier, 1856: 33. Synonymy in Lesne 1901: 624.

Apate lifuana Montrouzier, 1861: 267. Synonymy in Lesne 1896: 335.

Apate geoffroyi Montrouzier, 1861: 266. Synonymy in Borowski \& Węgrzynowicz 2019: 82.

Apate religiosae - Fairmaire 1850: 50 (in part).

\section{Diagnosis}

The species is distinguished from $X$. flavipes by the slightly smaller size and darker body, and the often entirely dark brown, fronto-clypeal suture with a median fovea. The middle of the lateral and posterior parts of the pronotum behind the asperities of recumbent teeth with extremely fine, moderate to sparse punctures. Punctures stronger on the disc of the elytra, three pairs of tubercles on the upper margin of the declivity not as developed as in X. flavipes, the lateral callus not converging into the lateral margin of the declivity. Elytral suture slightly raised, not as swollen as in X. flavipes, the apical angles raised a little without tubercles beneath the margin.

\section{Material examined}

Borowski \& Węgrzynowicz (2007) suggested that the type material of Apate religiosa could be in NHMUK and the Montrouzier types should be deposited in MNHN, but after the author examined 427 specimens of $X$. religiosus in NHMUK (plus one under $X$. geoffroyi), she did not find any one bearing a 'type' label. Similarly, no type specimens of Xylothrips were found in MNHN. Hence, the type material was not located, but the species is well-known in the archipelagos of the South Pacific Ocean, and in Australia.

The author has examined numerous specimens identified by Lesne and Vrydagh, and more than 1170 specimens were checked at several museums (RBINS, MIZPN, MNB, MTM, NHMUK, NMBS, NME, NMPC, NMS, NMW, SDEI, SNSD and ZSM) and in private collections (LYL, MAIC and PZP), but detailed locality data were not recorded. The specimens were mainly from Papua New Guinea, New Caledonia and the archipelagos of the South Pacific Ocean.

\section{Description}

Body. 5.5-8 mm long, about 2.2-2.35 times as long as wide, elongate. Entirely dark brown, except antennae, head and femora testaceous.

Head. Clypeus finely and densely punctured, almost glabrous in middle, concave in a wide arc in front with a tuft of erect, long and yellowish-red hairs on both sides of clypeus. Fronto-clypeal suture distinct, with median fovea. Frons with puncturation denser than on clypeus, slightly rough, covered by fairly long, fine pubescence directed upwards. First antennomere longer than wide, second antennomere shorter, each funicle segment with a rim of long hair on middle, total length of funicle as long as or shorter than first antennomere of antennal club, first two antennomeres of antennal club about 1.5 times as long as wide, last antennomere rather elongated, about 3 times as long as wide. Club matt, without clear sensory impression areas or erect hairs (Fig. 1E). 
Pronotum. 1.25-1.35 times as wide as long, fairly strongly narrowed in anterior third, widest in basal part; a distinct upwardly-directed uncinate tooth on anterolateral angle and a series of upward-directed teeth behind form lateral border of rasp on anterior half of pronotum, teeth gradually smaller and less erect towards summit of pronotum, posterior border of rasp formed by small tubercles or granules, bearing dense, white, short, recumbent pubescence between and on teeth (Figs 1E, 3A); area above anterior margin between uncinate teeth densely, finely and more or less roughly punctured; median and posterior areas of pronotum shiny with fine, sparse punctures, posterolateral areas with denser punctures and short, white-yellowish hairs; sides evenly rounded behind rasp; a distinct ridge-like lateral carina extends to basal margin of pronotum to form tip of posterolateral angles (Fig. 1F).

ELYTRA. 1.8-1.95 times as long as pronotum, 1.4-1.55 times as long as wide, parallel-sided at disc and widest at middle of declivity. Elytra shining, with sparse, fine and shallow punctures on disc, becoming deeper and larger towards lateral and posterior parts, upper half of declivity with strongest punctures. Entirely glabrous, with tiny white hairs along lateral and apical margins. Upper margin of elytral declivity with three pairs of tubercles, middle one largest and most strongly projecting, with pointed tip, other two forming short ridges with round ends, infero-lateral callus not extending to lower lateral margin of elytra (Fig. 3C-D). Elytral suture raised from middle of disc, gradually more swollen and thickest at upper margin of declivity, apex of declivity slightly projected.

AвDOMEN. Ventral side vestiture with dense, white or reddish yellow pubescence, last ventrite with narrow pleural pieces along margin.

LEGs. Dense, short golden hairs on ventroposterior margins of posterior femora. External face of pro- and mesotibiae narrowly grooved, not narrowed towards apex. Segments 2 and 3 of anterior tarsi distinctly wider than others.

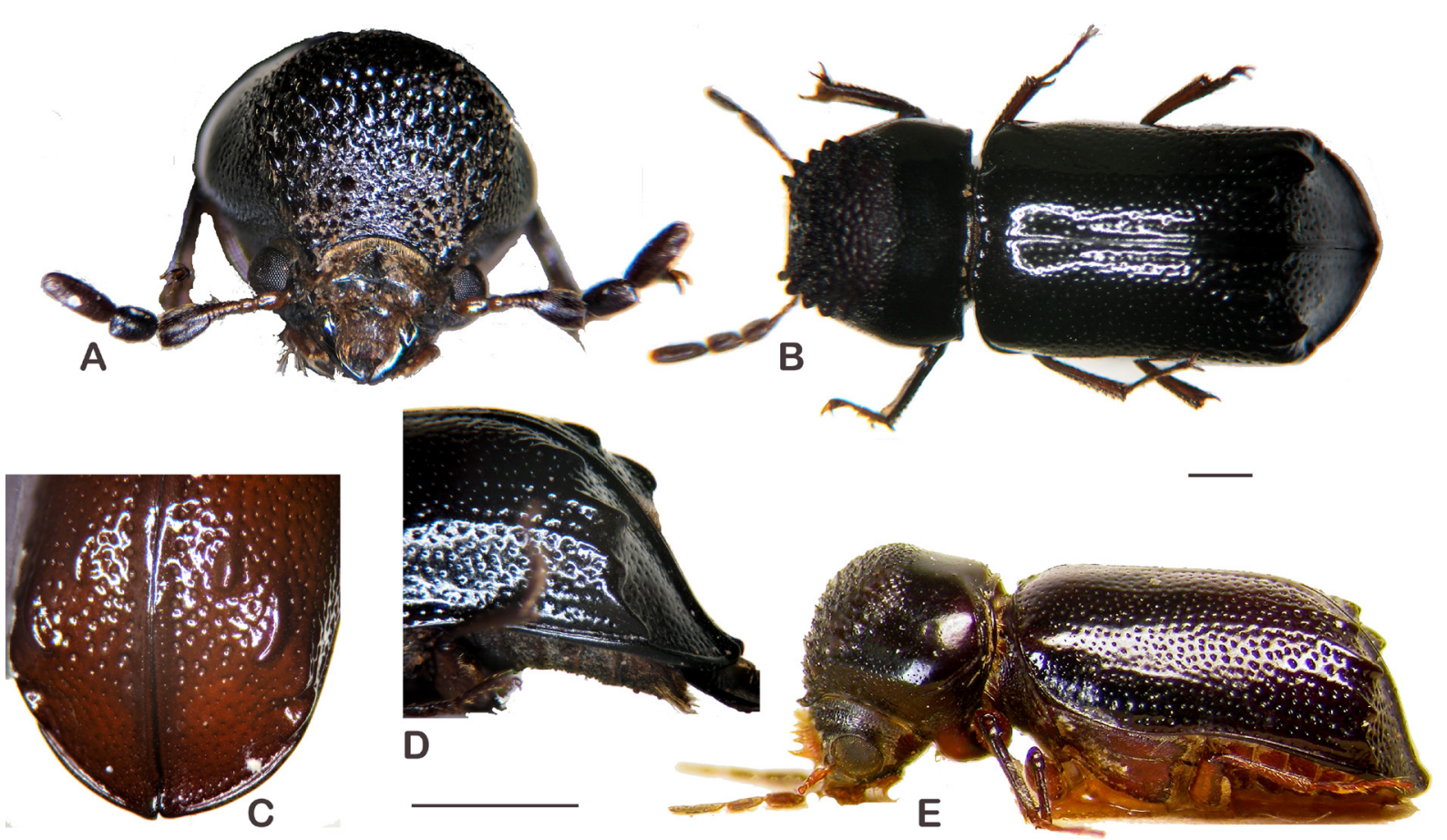

Fig 3. Xylothrips religiosus (Boisduval, 1835), $q$ (LYL). A. Frontal view. B. Dorsal view. C. Declivity. D. Lateral view of declivity. E. Lateral view. Scale bars $=1 \mathrm{~mm}$ (upper scale for B, E; lower scale for A, C-D). 


\section{Male}

HEAD. Frons transversely convex, densely and very finely punctured, a small shining callus in middle (Fig. 3A); yellow, erect pubescence covers areas from callus to eyes and fronto-clypeal suture, short and recumbent toward middle and gradually longer towards eyes, with a tuft of long, erect hairs next to inner margin of eyes. Clypeus with a transverse band of upwardly directed hairs towards base with a narrow median line and a tuft of long, erect hairs on both sides of clypeus (Fig. 1E).

\section{Female}

HEAD. Frontal crown of hairs very thick, forming arc of a circle or a very wide V, fairly distant laterally from eyes. Clypeal tufts of hairs as long as those on frons.

\section{Remarks}

Montrouzier (1861) described Apate lifuana and Apate geoffroyi from the Lifu and Art Islands of New Caledonia, respectively. Waterhouse (1888) transferred Apate lifuana to Xylopertha, noting that material he examined bore the name religiosa Dej. Lesne (1896) later synonymised Xylopertha lifuana with Xylothrips religiosus.

Borowski \& Węgrzynowicz (2019) synonymised Apate geoffroyi with X. religiosus without examination of the type material, but inferred that Montrouzier misinterpreted the differences between the sexes.

Lesne (1901) mentioned that specimens with reduced marginal tubercles of the elytral declivity are found in New Caledonia, and that one specimen from the Cape York peninsula, Australia was notable for the much stronger elytral punctures than found in other specimens, the very fine, but very distinct, punctures in the middle of the pronotal disc, and the weaker projection of the lowermost marginal tubercle of the elytral declivity. Variations in the punctures on the posterior half of the pronotum and in the development of the marginal tubercles of the elytral declivity were often found during the present study.

\section{Biology}

In Tahiti, X. religiosus has been recorded from the breadfruit tree (Moraceae: Artocarpus altilis (Parkinson) Forsberg), and in the 'bourao' (Malvaceae: Hibiscus tiliaceus L.). In Melanesia, the species attacks many trees, even the hardest ones, but its multiplication is reduced by a clerid beetle of the genus Cylidrus. The adults fly in the evening and are attracted to light (Lesne 1901).

\section{Distribution}

Indonesia, Papua New Guinea, Australia, New Caledonia and the archipelagos of the South Pacific Ocean. This species has been introduced to USA, Africa and Europe (Borowski \& Węgrzynowicz 2019).

Genus Calophagus Lesne, 1902 stat. res.

Figs $1 \mathrm{~A}-\mathrm{B}, 4$

Calophagus Lesne, 1902: 108 (type species: Calophagus pekinensis Lesne, 1902: 109).

This genus was erected by Lesne (1902) for the single Chinese species, Calophagus pekinensis. Reichardt (1966) described a new Chinese species, Xylothrips cathaicus, from the same area as C. pekinensis. Park et al. (2015) synonymised $X$. cathaicus with C. pekinensis as Xylothrips pekinensis based on the black and white figures of a new record of $X$. cathaicus from Tsushima Island, Japan (Iwata \& Kusakabe 2002) and a new record of $C$. pekinensis from the same location (Borowski \& Węgrzynowicz 2008), but without examining the type material of either species (S. Park, pers. comm.). Borowski \& Węgrzynowicz 
(2019) accepted the synonymy given by Park et al. (2015) and downgraded Calophagus to a subgenus of Xylothrips. They treated Xylothrips (Calophagus) pekinensis as a new combination.

Lesne (1902) deposited 5 syntypes of Calophagus pekinensis in MNHN, and Reichardt (1966) deposited the holotype and 3 paratypes of Xylothrips cathaicus in MCZ, and one paratype in the Department of Zoology, Saõ Paulo, Brazil. The author has examined the 5 syntypes of $C$. pekinensis in the R. Oberthür collection (MNHN), and the photos of the holotype of $X$. cathaicus from the Insect Type Database website of MCZ. Both agree with Lesne's description of $C$. pekinensis. The synonymy of $X$. cathaicus with $C$. pekinensis is confirmed. The reasons for the retention of Calophagus as a distinct genus are discussed below.

The distribution of the genus is confined to North China, South Korea and Tsushima Island in Japan.

\section{Type species}

Calophagus pekinensis Lesne, 1902, by monotypy.

\section{Diagnosis}

As a member of Xyloperthini Lesne, 1921, the genus closely resembles the preceding genus. It differs from Xylothrips in the following characters: rather dull, not as shining as the preceding genus; antennal club without clearly impressed sensory areas, but each of its three antennomeres with two longitudinal bands of golden hairs on each side of each face; pronotum without lateral carina, a few granules on the posterolateral angles form the tip of the angles; very fine punctures all over the elytra, the declivity abruptly declivous with three pairs of small tubercles on the upper margin, the middle one slightly larger, lateral callus small and close to lateral margin of the declivity.

Calophagus pekinensis Lesne, 1902

Figs $1 \mathrm{~A}-\mathrm{B}, 4$

Calophagus pekinensis Lesne, 1902: 109.

Xylothrips cathaicus Reichardt, 1966: 81-83.

\section{Material examined}

Syntypes of Calophagus pekinensis Lesne, 1902

CHINA • 5 syntypes; N China, Pekin; Abbe Armand David leg.; R. Oberthür Collection; MNHN.

Holotype of Xylothrips cathaicus Reichardt, 1966

CHINA • holotype; "11 // Peiping, Hopei, China, 193, G. Liu // M.C.Z. Type, 31194 // 659”; MCZ 31194.

The specific identity of more than 20 specimens was checked in several museums (RBINS, MNHN, NMBS, NMPC (as Xylothrips cathaicus) and SNSD) and private collections (LYL, MAIC and PZP (as $X$. cathaicus)), but detailed locality data were not recorded.

\section{Description}

Body. Stout, cylindrical, 6-8.5 mm long. Head deeply inserted in prothorax, not visible from above. Antennae, pronotum, elytral disc and profemur brown-red, other parts of body dark brown to black on ventral side. 
HEAD. Eyes rather large, oval, detached from temples posteriorly. Clypeus finely and densely punctured, anterior margin forming two arcs with a tooth in middle, anteriorly with a tuft of erect hairs, a band of long, yellowish-red hairs on transverse middle line. Fronto-clypeal suture distinct, with a vertical furrow. Frons with punctures denser than on clypeus, slightly rough, covered by fairly long, fine pubescence directed upwards, a small shining callus in middle (Fig. 4A). First antennomere longer than wide, second antennomere shorter, total length of funicle shorter than first segment of club; first antennomere of antennal club subtriangular, second antennomere of antennal club rectangular, about 1.2 times as long as wide, last antennomere rather elongated, about 2.5 times as long as wide. Each antennomere of antennal club with longitudinal bands of golden hairs on each side of each face (Figs 1A, 4A). Labrum yellowish, with dense punctures, fringed with long hairs on anterior margin. Both mandibles pointed at tip.

Pronotum. Slightly wider than long, fairly strongly narrowed in anterior third, widest in basal part; a distinct upwardly-directed uncinate tooth on anterolateral angle and a series of upwardly-directed teeth behind form lateral border of rasp on anterior half of pronotum, teeth gradually smaller and less erect towards summit of pronotum; posterior margin of rasp formed by small tubercles or granules, bearing sparse, yellowish-red, short, recumbent pubescence between and on teeth (Fig. 4A); area above anterior margin between uncinate teeth finely and more or less roughly punctured; posterior half of pronotum very smooth, impunctate; sides evenly rounded behind rasp; lateral carina absent, posterolateral angles rectangular, with a few small granules on tip (Figs 1B, 4B); anterolateral part of pronotum with sparse punctures with dense, long, white, recumbent pubescence (Figs 1B, 4A).
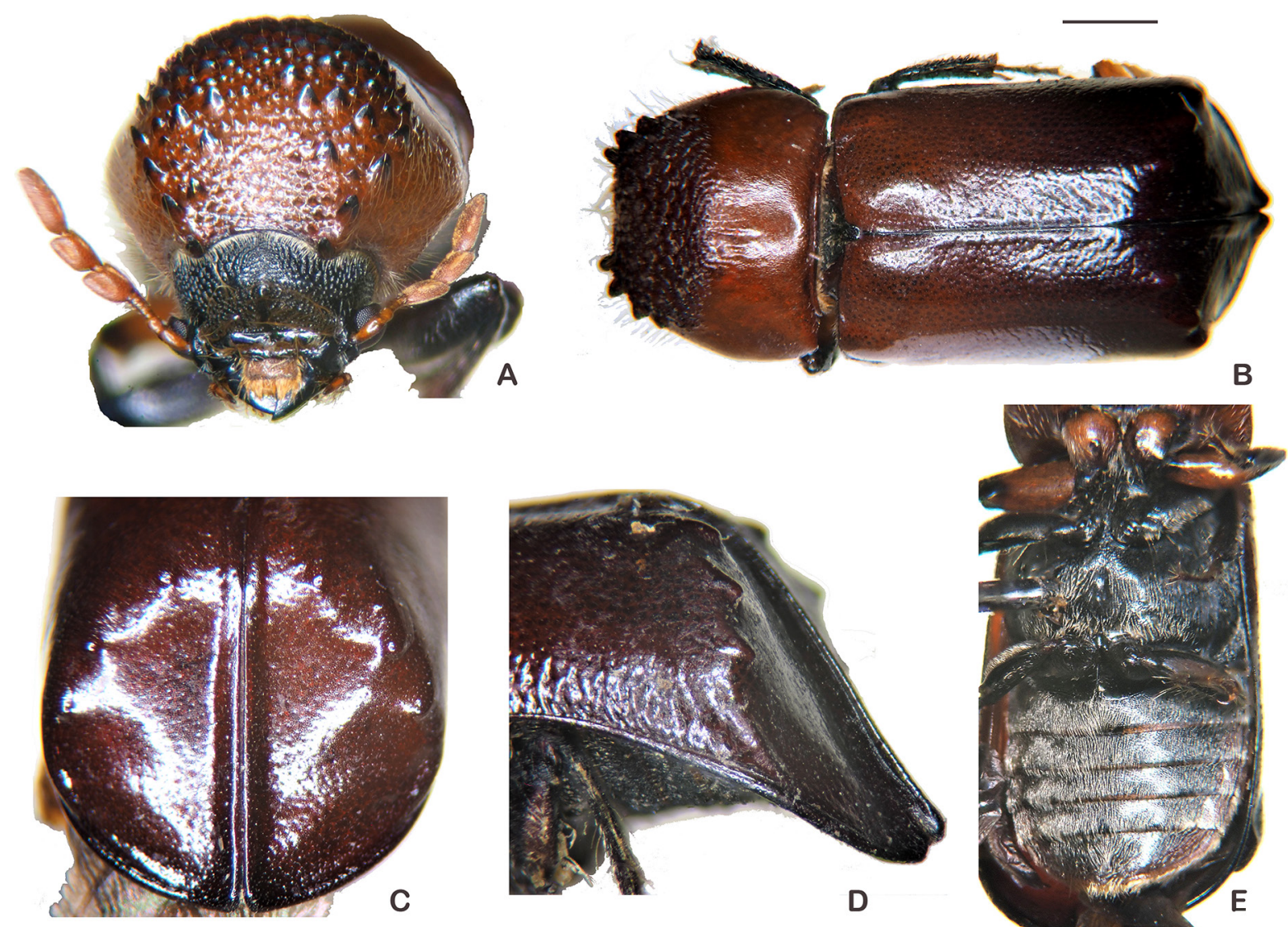

A

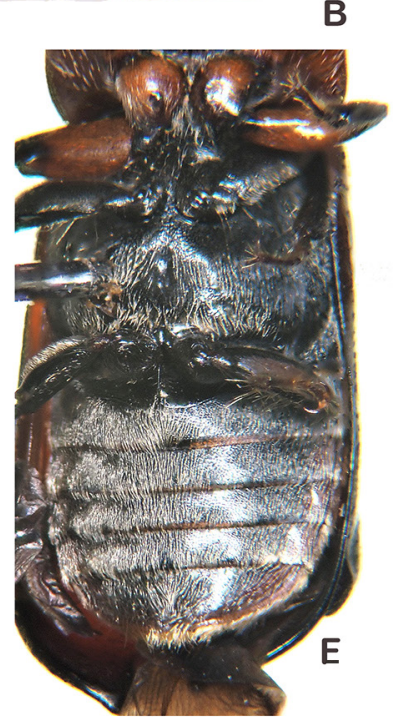

Fig. 4. Calophagus pekinensis Lesne, 1902, q (SNSD). A. Frontal view. B. Dorsal view. C. Declivity. D. Lateral view of declivity. E. Ventral view. Scale bars $=1 \mathrm{~mm}$ (upper scale for B, E; lower scale for A, C-D). 
ELYTRA. Punctures of elytra fairly fine, superficial, obsolete anteriorly and near margins of apical declivity; declivity shining and very smooth, very obscurely punctured, margined on each side by three subequal blunt tubercles and by an infero-apical callus in form of a fold, separated from elytral margin by marginal groove (Fig. 4C-D). Suture slightly projecting on declivity, weakly reflexed at apex.

ABDOMEN. Covered with grey, appressed pubescence, very dense and quite long, last ventrite with pleural pieces along lateral margins.

LEGS. Dense, short golden hairs on ventroposterior margins of metafemora. Anterior face of anterior tibiae uniformly pubescent, external face of posterior tibiae with numerous, long golden hairs. Segments 2 and 3 of anterior tarsi distinctly wider than others.

\section{Male}

HEAD. Frons transversely convex, densely and very finely punctured, a small shining callus in middle (Fig. 4A), yellow erect pubescence covers areas from callus to eyes and fronto-clypeal suture, short and recumbent toward middle and gradually longer closer to eyes, with a tuft of long, erect hairs next to inner margin of eyes. Clypeus with a transverse band of upwardly directed hairs towards base, with a narrow median line (Fig. 4A).

ABDOMEN. Last ventrite with pleural pieces, foveolate in middle behind apical margin.

\section{Female}

HEAD. Frontal crown of hairs very thick, forming arc of a circle or a very wide V, fairly distant laterally from eyes. Clypeus with a transverse band of upwardly directed, long hairs towards base, with a narrow median line.

AвDomen. Last ventrite with pleural pieces, impression in middle behind apical margin shallower than in male.

\section{Remarks}

The specimens from South Korea are more shining, particularly on the apical half of the elytra, which may be almost as shining as in Xylothrips flavipes. The specimens from China and Tsushima Island are rather matt. The lateral callus on the elytral declivity is more reduced in the male than in the female, and is almost lost in the male from Tsushima Island, with only a short carina remaining.

\section{Biology}

Iwata \& Kusakabe (2002) recorded 8 males and 13 females of Xylothrips cathaicus from dead branches of Zelkova serrata (Thunb.) Makino (Ulmaceae) in April, 1990, on Tsushima Island, Japan. Chen (1990) recorded 4 males and 6 females of Xylothrips cathaicus collected from Styphnolobium japonicum (L.) Schott (Leguminosae) in April, 1987, in Beijing. Zhan (1984) studied the "common pest", Calophagus pekinensis, of timber and the wood used in the construction of houses in Hubei, China, and found that the species has one generation per year. The developmental periods of the immature stages were: eggs 8-10 days; larvae about 110 days; pupa about 12 days. Adults lived for about 230 days in Hubei, China and bred in Pterocarya stenoptera C.DC. (Juglandaceae). The clerid beetles Tarsostenus univittatus (Rossi, 1792) and Tillus notatus Klug, 1842 prey on larvae and pupae (Zhan 1984). Doryctinae Forster, 1862 (Hymenoptera: Braconidae Latreille, 1829) and Bethylidae Forster, 1856 (Hymenoptera) were observed to be parasitic on larvae and pupae during the study (Zhan 1984). In 2008, the author received a series of specimens from Shandong, China collected from Rosa rugosa Thunb. (Rosaceae) in Aug. 2007. S. Park collected specimens of this species from the freshly cut wood of an apple tree (Rosaceae: Malus domestica Borkh.) in an orchard, together with Xylosandrus spp. (Scolytinae). It is also known to attack Chionanthus retusus Lindl.\&Paxton (Oleaceae) (S. Park, pers. comm.). 


\section{Distribution}

South Korea, Japan (Tsushima Island), North China (Hebei, Henan, Hubei, Shandong).

\section{Key to species of Xylothrips and Calophagus}

1. Each antennomere of antennal club with a band of golden hairs on both sides of each face; pronotum without lateral carina; punctures on elytra very fine and sparse; three pairs of marginal tubercles of declivity very reduced (Figs $1 \mathrm{~A}-\mathrm{B}, 4)$

Calophagus pekinensis Lesne, 1902

- Antennal club matt without sensory impression or hair bands; pronotum with ridge-like lateral carina; punctures on elytra deeper and denser; three pairs of marginal tubercles of declivity well developed (Figs 1C-F, 2-3)

2. Posterolateral sides of pronotum shining, glabrous without punctures; lateral callus converging into lateral margin of declivity; round tubercles on apical sutural angle of declivity. Male: frons without erect bristles in the middle or only with some bristles arranged in an arc

Xylothrips flavipes (Illiger, 1801)

- Posterolateral sides of pronotum with sparse to moderately dense punctures; lateral callus not converging into lateral margin of declivity; apical suture angle of declivity without tubercle. Male: with frontal crown formed by short but dense bristles .......Xylothrips religiosus (Boisduval, 1835)

\section{Discussion}

The tribe Xyloperthini has the most genera (34, after the reinstatement of Calophagus) in the entire family Bostrichidae. Lesne (1901) in his monograph of the tribe, and in later studies on the tribe (Lesne 1924, 1932, 1938b), based his separation of the genera primarily on two characters: 1) the distribution and characters of the sensory areas of the antennae, which he said "provided the best guide to the systematist" to distinguish the many varied forms, and 2) the presence or absence of a ridge-like lateral suture on the prothorax. Lesne (1902) used these two characters to distinguish his new genus Calophagus from Xylothrips. In Xylothrips, the antenna is matt, without any sensory impressions or areas with special stiff hairs; in Calophagus, each of the three segments of the antennal club has two narrow longitudinal bands of golden pubescence. In Xylothrips, there is a distinct lateral suture on the prothorax; in Calophagus, there are at most a few granules on the posterior angles of the prothorax.

Later authors (Reichardt 1966; Park et al. 2015; Borowski \& Węgrzynowicz 2019) have mentioned the difference in the lateral suture between the two genera, but have completely ignored the major difference between the antennae. They then considered that the difference in the lateral suture between the genera is unimportant, and synonymised the two, based on a general similarity of habitus. The author suggests that they allowed superficial similarities to obscure much deeper phylogenetic differences. Liu \& Schönitzer (2011) divided the character 'sense area location on antennal club' into eight groups. Calophagus is the only genus in the Xyloperthini that falls into their group 5 (sensory areas on middle part of both sides). The other genus that falls into this group is Amphicerus LeConte, 1861, an unrelated genus in the tribe Bostrichini, and there are distinct differences between the antennae of the two genera. Xylothrips falls into group 0 (no special sensory areas) in Liu \& Schönitzer's study. It is clear that Xylothrips and Calophagus are phylogenetically distinct genera. Therefore, Calophagus is reinstated as a separate genus.

The very similar morphology and neighbouring distribution of the two genera may have resulted in the misinterpretations of previous authors (Reichardt 1966; Park et al. 2015; Borowski \& Węgrzynowicz 2019). This study attempts to resolve the problem, and forms the third paper in a larger project which will try to resolve some of the problems existing in the classification of the tribe Xyloperthini. Due to the lack of DNA information for Bostrichidae (O. Zimmermann (LTZ, Germany), pers. comm.), more DNA studies of Bostrichidae are needed to completely clarify the relationship of the various genera. 


\section{Acknowledgements}

The author appreciates Dr Sangwook Park, who offered much information on Calophagus pekinensis, and is most grateful to the following curators who have allowed me access to the collections in their charge or who have sent specimens for examination and identification: D. Mierzwa (MIZPAN), B. Jäger (MNB), A. Taghavian (MNHN), O. Merkl (MTM), M. Barclay (NHMUK), M. Brancucci ${ }^{\dagger}$ (NMBS), Matthias Hartmann (NME), V. Švihla ${ }^{\dagger}$ (NMPC), H. Schönmann ${ }^{\dagger}$ (NMW), P. Limbourg (RBINS), L. Zerche (SDEI), W. Schawaller (State Museum of Natural History, Stuttgart), K-D. Klass (SNSD) and M. Balke (ZSM). I also wish to thank Dr Petr Zahradnik and Dr Michael Ivie, who allowed me to examine their private collections.

\section{References}

Beeson C.F.C. \& Bhatia B.M. 1937. On the biology of the Bostrychidae (Coleopt.). Indian Forest Records (New Series) Entomology 2: 223-323.

Boisduval J.B.A. 1835. Voyage de découvertes de l'Astrolabe, exécuté par ordre du roi, pendant les années 1826-1827-1828-1829, sous le commandement de M.J. Dumont d'Urville. Faune entomologique de l'Océan pacifique, avec l'illustration des insectes nouveaux recueillis pendant le voyage. Deuxième Partie. Coléoptères et autres Ordres VIII. J. Tastu, Paris.

Available from https://www.biodiversitylibrary.org/page/34906495 [accessed 23 Mar. 2021].

Borowski J. \& Węgrzynowicz P. 2007. World Catalogue of Bostrichidae (Coleoptera). Wydawnictwo Mantis, Olsztyn, Poland.

Borowski J. \& Węgrzynowicz P. 2008. Calophagus pekinensis Lesne, 1901, a bostrichid beetle new to the Japanese fauna. Elytra 36 (2): 285-286.

Borowski J. \& Węgrzynowicz P. 2019. Nomenclatural changes in the genus Xylothrips Lesne, 1901 (Coleoptera, Bostrichidae, Xyloperthini). World News of Natural Sciences 24: 79-88.

Chen S. 1990. Note on male of Xylothrips cathaicus Reichardt (Coleoptera: Bostrychidae). Acta Zootaxonomica Sinica 15 (2): 255.

Chûjō M. 1937. Family Bostrychidae, Family Lyctidae. Class Insecta, Coleopteroidea - Coleoptera. Fauna Nippon 10 (8-7): 1-103.

Fabricius J.C. 1801. Systema Eleutheratorum secundum Ordines, Genera, Species: adiectis Synonimis, Locis, Observationibus, Descriptionibus. Volume 2. Bibliopoli Academici Novi, Kiliae [Kiel, Germany].

Fisher W.S. 1950. A revision of the North American species of beetles belonging to the family Bostrichidae. Miscellaneous Publications, United States Department of Agriculture 698: 1-157. https://doi.org/10.5962/bhl.title.65663

Fairmaire L. 1850. Essai sur les coléoptères de la Polynésie. Revue et Magasin de Zoologie, Series 22 : 50-64. Available from https://www.biodiversitylibrary.org/page/2339927 [accessed 8 Apr. 2021].

Illiger J.K.W. 1801. Neue Insekten. Magazin für Insektenkunde 1(1-2): 163-208.

Ivie M.A. 2010. Additions and corrections to Borowski \& Wêgrzynowicz's world catalogue of Bostrichidae (Coleoptera). Zootaxa 2498 (1): 28-46. https://doi.org/10.11646/zootaxa.2498.1.2

Iwata R. \& Kusakabe Y. 2002. New record of Xylothrips cathaicus (Coleoptera, Bostrychidae) from the Tsushima Islands, Japan. Elytra 30 (2): 429-430.

Lesne P. 1896. Notes synonymiques sur les bostrychides hypocéphales (Col.). Bulletin de la Société entomologique de France 14: 334-335. https://doi.org/10.5962/bhl.title.9565

Lesne P. 1901. Revision des coléoptères de la famille des bostrychides. $4^{\mathrm{e}}$ mémoire. Bostrychinae sens. strict. II. Les Xylopertha. Annales de la Société entomologique de France 69: 473-639. 
Lesne P. 1902. Synopsis des bostrychides paléarctiques. L'Abeille, Journal d'Entomologie 30: 105-136.

Lesne P. 1921. Classification des coléoptères xylophages de la famille des bostrychides. Comptes rendus de l'Association française pour l'Avancement des Sciences 1920: 285-289. Available from http://www.biodiversitylibrary.org/item/27278\#page/289/mode/ [accessed 23 Mar. 2021].

Lesne P. 1924. Les coléoptères bostrychides de l'Afrique tropicale française. In: Bouvier E.-L. (ed.) Encyclopédie entomologique, volume III. Les Presses universitaires de France, Paris.

Lesne P. 1932. Coléoptères des Îles Mascareignes (mission scientifique de P. Caerié, 1910-1913). Bostrychides, clerides, supplement aux buprestides. Annales de la Société entomologique de France 101: 1-24.

Lesne P. 1938a. Bostrychidae. In: Schenkling S. (ed.) Coleopterorum Catalogus, pars 161. Wilhelm Junk, Berlin.

Lesne P. 1938b. Entomological expedition to Abyssinia, 1926-7: Coleoptera, Bostrychidae. The Annals and Magazine of Natural History, Series 112 (10): 387-395.

https://doi.org/10.1080/00222933808526865

Liu L.Y. \& Beaver R.A. 2017. A review of the powder-post beetle genus, Xylopertha Guérin-Méneville, 1845, with a new species and new synonymy (Coleoptera: Bostrichidae: Bostrichinae: Xyloperthini). European Journal of Taxonomy 380: 1-22. https://doi.org/10.5852/ejt.2017.380

Liu L.Y. \& Schönitzer K. 2011. Phylogenetic analysis of the family Bostrichidae auct. at suprageneric levels (Coleoptera: Bostrichidae). Mitteilungen der Münchener entomologischen Gesellschaft 101: 99132.

Liu L.Y., Beaver R.A. \& Sanguansub S. 2016. A new Oriental genus of bostrichid beetle (Coleoptera: Bostrichidae: Xyloperthini), a new synonym and a lectotype designation for Octodesmus episternalis (Lesne, 1901). European Journal of Taxonomy 189: 1-12. https://doi.org/10.5852/ejt.2016.189

Montrouzier X. 1856. Essai sur la faune de l'Ile de Woodlark ou Moiou. Annales de la Société imperiale d'Agriculture, d'Histoire naturelle et des Arts utiles de Lyon, Series 2 7: 1-226.

Montrouzier P. 1861. Essai sur la faune entomologique de la Nouvelle-Calédonie (Balade) et des îles des Pins, Art, Lifu, etc. Coléoptères (fin). Annales de la Société entomologique de France, Series 41 : 265-306.

Park S., Lee S. \& Hong K.-J. 2015. Review of the family Bostrichidae (Coleoptera) of Korea. Journal of Asia-Pacific Biodiversity 8: 298-304. https://doi.org/10.1016/j.japb.2015.10.015

Reichardt H. 1966. Bostrichidae (Coleoptera) 7: A new Xylothrips from China. The Coleopterists' Bulletin 20: 81-83.

Roberts H. 1968. A new powder-post beetle, Xyloperthella guineensis, together with an annotated check list of the subfamily Bostrychinae (Col., Fam. Bostrychidae) from Nigeria. Journal of Natural History 2: 85-104. https://doi.org/10.1080/00222936800770641

Sittichaya W., Thaochan N. \& Wattanachai T. 2013. Powderpost beetle communities (Coleoptera: Bostrichidae) in durian-based agricultural areas in Southern Thailand. Kasetsart Journal - Natural Science 47: 374-386.

Snellen van Vollenhoven S.C. 1869. Description des espèces nouvelles de coléoptères, orthoptères, lépidoptères et hémiptères, mentionées dans la liste précedente. In: Snellen van Vollenhoven S.C. \& de Selys Longchamps E. (eds) Insectes. Recherches sur la Faune de Madagascar et ses Dépendances, d'après les Découvertes de François P.L. Pollen et D.C. van Dam. Part 5, Issue 1. J.K. Steenhoff, Leyde [Leiden, the Netherlands]. 
Stebbing E.P. 1914. Indian Forest Insects of Economic Importance: Coleoptera. Eyre \& Spottiswoode, London. https://doi.org/10.5962/bhl.title.9203

Walker F. 1858. Characters of some apparently undescribed Ceylon insects. Annals and Magazine of Natural History, Series 32 (10): 280-286. https://doi.org/10.1080/00222935808697026

Waterhouse C.O. 1888. XLIV. Some observations on the coleopterous family Bostrichidae. Annals and Magazine of Natural History, Series 61 : 348-350. https://doi.org/10.1080/00222938809460741

Zhan Z. 1984. Preliminary report on Calophagus pekinensis Lesne (Coleoptera, Bostrychidae). Scientia Silvae Sinicae 20 (2): 217-219.

Manuscript received: 21 September 2020

Manuscript accepted: 25 January 2021

Published on: 23 April 2021

Topic editor: Nesrine Akkari

Section editor: Max Barclay

Desk editor: Danny Eibye-Jacobsen

Printed versions of all papers are also deposited in the libraries of the institutes that are members of the EJT consortium: Muséum national d'histoire naturelle, Paris, France; Meise Botanic Garden, Belgium; Royal Museum for Central Africa, Tervuren, Belgium; Royal Belgian Institute of Natural Sciences, Brussels, Belgium; Natural History Museum of Denmark, Copenhagen, Denmark; Naturalis Biodiversity Center, Leiden, the Netherlands; Museo Nacional de Ciencias Naturales-CSIC, Madrid, Spain; Real Jardín Botánico de Madrid CSIC, Spain; Zoological Research Museum Alexander Koenig, Bonn, Germany; National Museum, Prague, Czech Republic. 